\title{
The Hungarian Fundamental Law, the New Cardinal Laws and European Concerns
}

\begin{abstract}
The article examines the new trends of Hungarian constitutionalism, which have been realized in the new Fundamental Law and that raises some questions with regard to, among other things, the hierarchy of sources of law. Especially the cardinal laws have been the subject of criticisms both within the Hungarian doctrine that by experts in constitutional law and international organizations in the Western world. From the point of view of comparative constitutional law, it should be noted that reinforced laws are provided in many constitutions, in both Western and Eastern Europe. In order to better understand the role of cardinal laws is useful to consider, first of all and in addition to the new Fundamental Law, the system of pre-existing organic laws of Hungary. Furthermore, it is also interesting to consider, on the one hand, the first cardinal laws approved, and, on the other hand, the orientations of the Hungarian Constitutional Court on organic laws prior to the adoption of the new Fundamental Law.
\end{abstract}

Keywords: Hungarian constitutionalism, new Hungarian Fundamental Law, hierarchy of sources of law, cardinal laws

1. Among the controversial aspects of the "Partisan" Hungarian Constitution, criticized both by the Hungarian scholarship and the European institutions, there are some aspects regarding the sources of law ${ }^{1}$ governed by the new Fundamental Law. In the Fundamental Law that came into force on 1 January $2012^{2}$ there is, on the system of norms, a first

* Associate professor, University of Bergamo, Department of Law, via Moroni 255 - 24127 Bergamo (BG), Italy.

E-mail: mauro.mazza@unibg.it

${ }^{1}$ For the importance of the system of sources of law in the study of comparative constitutional law see, in the Italian legal literature, Pizzorusso, A.: Sistema delle fonti e forma di Stato e di governo. Quaderni costituzionali, 1986, $217 \mathrm{ff}$., where the author investigates the existence of a relationship between the hierarchy of sources depending on the intensity of their legal effect and hierarchy of the state bodies according to their degree of representativeness. In general, on the primary role of the (individual) sources of law for the knowledge of public/constitutional law (of any country), see ex multis Groppi, T.-Simoncini, A.: Introduzione allo studio del diritto pubblico e delle sue fonti. Torino, 2011; Palermo, F.: La produzione giuridica e i sistemi delle fonti. In: Carrozza, P.-Di Giovine, A.Ferrari, G. F. (eds): Diritto costituzionale comparato. Roma-Bari, 2011, 3rd ed., 819 ff; Pino, G.: La gerarchia delle fonti del diritto. Costruzione, decostruzione, ricostruzione. In: Ars interpretandi. Annuario di ermeneutica giuridica. 2011, 19 ff., who examines criteria of hierarchy and competence in the construction of the system of sources, noting that to determine the order of the rules is as important as producing them and perhaps even more.

2 See the analytical comments, relating to (also) the system of sources, of Kovács, K.-Tóth, A. G.: Hungary's Constitutional Transformation. European Constitutional Law Review, 2011, 183 ff., and Kovács, G.: Ungarns neue Verfassung - In Kraft 1. Januar 2012. Osteuropa Recht, 2011, 253 ff. In the Italian legal doctrine, see Ferrari G. F. (ed.): La nuova Legge fondamentale ungherese. Torino, 2012. A recent comparative picture on the constitutional democracies of Central Europe was carried out by Tóth, A. G.: From Uneasy Compromises to Democratic Partnership: The Prospects of Central European Constitutionalism. Acta Juridica Hungarica, Hungarian Journal of Legal Studies, 2011, $220 \mathrm{ff}$, also published with some modifications in the European Journal of Law Reform, 2011, $80 \mathrm{ff}$. 
arrangement, represented by Article R, which does not seem to cause particular issues, unlike the subsequent rulings of Article $\mathrm{T}$, that, however, led to severe criticism, both international and "domestic".

Article $\mathrm{R}$ is limited, in fact, to establish that the Fundamental Law is the essential basis of the Hungarian legal system, and that the constitutional provisions are superior to the laws passed by the National Parliament. ${ }^{3}$ Nor does it seem innovative, in view of comparative Eastern European post-socialist law, in the fact that the third paragraph of Article R claims specifically that the provisions of the Fundamental Law shall be construed in accordance with the statements contained in the Preamble to the Constitution. ${ }^{4}$ Given, in fact, that the Preamble of the Constitution is inserted after the heading »Fundamental Law «, in line with what has previously been noted by a careful analysys specifically dedicated to a comparative perspective of the legal nature of the preambles of the constitutions of postcommunist Eastern Europe, ${ }^{5}$ does not appear that there may be doubts about the legally mandatory and not merely political-programmatic character of the Preamble of the new Hungarian Fundamental Law. More specifically, by virtue of reference ${ }^{6}$ by which the Preamble is an integral part of the Fundamental Law, and to the extent that the Preamble is placed after the naming of the Constitution, it follows that the Preamble does not have the same direct normative character ${ }^{7}$ as the other constitutional provisions, but still exerts

${ }^{3}$ See the first paragraph of art. R.

${ }^{4}$ See the careful analysis of the importance and role of the preambles of the constitutions of post-communist countries of Eastern Europe conducted by Kutlešić, V.: Les constitutions postcommunistes européennes. Étude de droit comparé de neuf États, foreword by Milačić, S. Brussels, Bruylant, 2009, $17 \mathrm{ff}$. (translated from the original in Serbian language). The solution was not different in Socialist countries: see Jovii, M.: O ustavu [On Constitution]. Beograd, Savremena administracija, 1977, 138, which affirms the legal strength of texts (preambles, attachments, etc.) that are an integral part of the Constitution. On the theme, a classic is the study of Häberle, P.: Präambeln im Text und Kontext von Verfassungen. In: Listl, J.-Schambeck, H. (eds): Demokratie in Anfechtung und Bewährung. Festschrift für J. Broermann. Berlin, 1982, $211 \mathrm{ff}$., where the distinction between the preamble to the constitution and the preamble of the constitution. More recently, see Orgad, L.: The preamble in constitutional interpretation. International Journal of Constitutional Law, 2010, $714 \mathrm{ff}$., who distinguishes the three types of symbolic preamble, interpretive preamble and substantive preamble. In Italy, see Frosini, J. O.: Il preambolo. Quaderni costituzionali, 2003, 387 ff., who critically discusses the legal nature of the preambles of the constitutions, moving from the minimum level of mere proclamation (devoid of any legally binding), then considering the intermediate level of programmatic value and finally achieving the maximum value (even ) "super-constitutional". On the question of the value attributable to the introductory texts of constitutions, as a matter under consideration in the comparative-historical perspective, see now Coutant, A.: De la valeur d'un texte introductif: la Constitution française de 1848 et son Préamble. Revue française de droit constitutionnel, 2011, $681 \mathrm{ff}$. There are, of course, in comparative constitutional studies positions that instead tend, already many years ago, to limit the importance of the introductory texts of constitutions: in this sense, see mainly the reflections of Esmein, A.: Eléments de droit constitutionnel français et comparé (1889). Paris, Éditions Panthéon-Assas/Librairie générale de droit et de jurisprudence, 2001 (réédition), $554 \mathrm{ff}$.

5 See Kutlešić: op. cit. $17 \mathrm{ff}$.

${ }^{6}$ In the third paragraph of Article R of the Fundamental Law.

7 That is, a binding force. 
considerable influence in terms of primary standards, as required by the fundamental goals and values of the constitutional order. Ultimately, the Preamble of the new Hungarian lex fundamentalis influences the adoption, interpretation and application of the other lowerlevel norms.

2. Not little controversial issues are concerning Article $T$ of the Fundamental Law of Hungary. The constitutional provision in question provides for the adoption and amendment of the so-called cardinal laws, or organic laws, ${ }^{8}$ for whose approval is required the majority of two thirds of the votes cast by members present in the Parliament.

From a theoretical point of view, organic laws have a dual function, which determines a certain ambiguity of the laws themselves. On the one hand, they serve to secure the parliamentary minorities in respect of decisions that may be adopted by transient majorities. On the other hand, organic laws are likely to determine rigidities concerning some choices of the legislature, in order to make parliamentary decisions more difficult to modify in the course of subsequent legislatures. ${ }^{9}$ This margin of ambiguity, as discussed in the pages that follow, it is significantly expressed in the new Hungarian constitutional order, in view of the wide use by the new Fundamental Law of the institution of cardinal laws.

The provision of Article $\mathrm{T}$ has been widely criticized, both internationally and by Hungarian scholars. Starting from the latter, very interesting as it allows to know the "internal" point of view, it was observed ${ }^{10}$ that the provision introduces a kind of limitation to the realization of the democratic will, to the extent that the voters who do not approve the line of conduct of the government in office can only with difficulty obtain a change of government policy in successive legislatures, since the simple majority cannot change what was previously established by cardinal/organic laws. The discipline enacted by cardinals laws is, in fact, less flexible than the one provided by ordinary laws. Problems arise considering that there are numerous cases in which the Fundamental Law provides the necessary adoption of a cardinal law.

Such cases are related to thirty nine areas of the legal order. ${ }^{11}$ They are, inter alia but primarily, the field of family discipline, the Fundamental Law stipulates that the marriage is

8 In Hungarian, sarkalatos törvény.

9 See de Morais, C. B.: Le finalità politiche delle leggi rinforzate. Quaderni costituzionali, 1998, $27 \mathrm{ff}$. On the category of »leggi rinforzate«, in relation to the Italian legal system, see Ferrari, G.: Le leggi rinforzate nell'ordinamento italiano. Id., Studi sulla Costituzione, Milano, 1958, II, 479 ff., who examines the articles 99, 132 and 133 of the Italian Constitution.

10 See Chronowski, N.: The New Hungarian Constitution in the European Context University of Trento European Coustitutional Law Student's Seminar Series. See also the views expressed at the Roundtable Discussion »Debating the Hungarian Constitution«, held March 2, 2012 at the Department of Political and Social Sciences of the European University Institute (EUI) in Badia Fiesolana (Florence), with speeches by József Szájer, Zita Gurmai, Gábor Halmai and András Jakab, to which are to be added the views of Hamza, G. Puppinck and R. Toniatti at the conference »Concetti e principi del diritto romano e la nuova Costituzione ungherse «, held in Rome March 12, 2012 at the Department of Law of the University LUMSA (Libera Università Maria Ss. Assunta), as well as of Roberto Toniatti and Laura Montanari at the study meeting on »Europa e democrazia: il caso ungherese«, held at the Law Faculty of the University of Parma April 20, 2012.

11 See the detailed examination of Csink, L.-Schanda, B.-Varga, A. Z. (eds): The Basic Law of Hungary. A First Commentary. Dublin (National Institute of Public Administration-NIPA/Nemzeti Közigazgatási Intézet-NKI, Hungary), 2012, 16 ff. 
provided solely when the union is between man and woman, according to the third paragraph of Article L. Many aspects are related to the organization of public powers, such as the appointment of ministers and other senior civil servants, under the fourth paragraph of Article 17, and the term of office of the administrative authorities responsible for regulation and control, who are appointed by the Prime Minister or, at the proposal of the same, by the President of the Republic, as well as the scope of the powers conferred to the heads of autonomous regulatory bodies, based on the provisions contained, respectively, in the second and fourth paragraph of Article 23. There are also key aspects of the judicial system, namely the organization and administration of the courts and the legal status and remuneration of judges, in accordance with the provisions in the seventh paragraph of Article 25. Are contemplated very large areas, which are indicated in Article 40 of the Constitution, i.e. the basic rules of public finance, the pension system and provisions for public service delivery. The cardinal laws are relating to financial institutions and control, such as the provisions concerning the organization and operation of the State Audit Office, in accordance with the provisions contained in the fourth paragraph of Article 43, and the operational rules regarding the Budget Council, as provided for by the fourth paragraph of Article 44. Cardinal laws are provided with respect to the supreme command of the Armed Forces, attributed to Parliament, President, National Council of Defense, Government and Minister responsible, on the basis of the Constitution and of (one or more) cardinal laws, as stipulated in the second paragraph of Article 45 of the Fundamental Law, ${ }^{12}$ and also for the rules concerning the organization and functioning of the police and national security services, as well as provisions relating to methods of espionage and intelligence agencies, according to the sixth paragraph of Article 46. Last but not least, cardinal laws are to regulate both individual and collective rights of nationalities, that of national minorities, as well as rules for the election of their self-governing bodies both local and national, pursuant to the provisions in the third paragraph of Article $29 .{ }^{13}$

12 The fifth and last paragraph of Article 45 of the Fundamental Law further states that the detailed rules on organization, tasks, supreme command, management and practical operation of the Hungarian Armed Forces should be established through the adoption of a cardinal law.

13 For a few brief remarks on the matters to be regulated by cardinal laws, see: Kelemen, K.: Una nuova Costituzione per l'Ungheria. Quaderni costituzionali, 2011, specifically 682 f; Di Gregorio, A.: La Costituzione ungherese del 25 Aprile 2011: è davvero tutto così nuovo? Qualche osservazione in libertà, working papers published on the website »Diritto Pubblico dei Paesi dell'Europa Orientale (DIPEO)«, available at http:// users. unimi. it/ dirpubesteuropa (doc. dated 9-72011); De Capitani, E.: Unione europea e Ungheria: verso un nuovo caso »Haider «?, in the website »Diritti Comparati. Comparare i diritti fondamentali in Europa (doc. dated 11-1-2012), who (sub La riforma costituzionale ungherese nel contesto dello spazio pubblico dell'Unione) speaks of thirty laws that must be approved to implement the new constitutional text. Most widely, see Courrier, A. E.: À propos des «évènements politiques en Hongrie«... Quelques clés pour en comprendre le débat juridique. Revue internationale de droit comparé, 2012, 310 ff. (sub II, L'objet du débat - Les lois cardinales, 315 ff.). On the controversial political-party background of the new Hungarian Fundamental Law, see for example: Bottoni, S.: L’Ungheria di Viktor Orbán. Il Mulino. Rivista bimestrale di cultura e di politica, 2011, 1006 ff; Rühle, A.: Populismo di governo a Budapest. Internazionale, June (2011) 900, 38 ff; Fabbrini, F.: L'Ungheria, i diritti fondamentali e l'Unione Europea: è tempo di attivare l'art. 7 TUE?, in the website »Diritti Comparati. Comparare i diritti fondamentali in Europa (at the Internet address cited supra, doc. dated 16-1-2012); Dau, F.: Ungheria - La Commissione europea avvia la procedura di infrazione, in the website »Diritto Pubblico dei Paesi dell'Europa Orientale (DIPEO)« (doc. dated 29-1-2012); Pidd, H.: La svolta dell'Ungheria. 
In the Hungarian legal literature it has been criticized, in particular, the choice to regulate by cardinal laws the areas of social policy and the tax, as it addresses matters that would otherwise require an adequate degree of flexibility. ${ }^{14}$

The reservations expressed with regard to the constitutional discipline of cardinal laws by a part of the Hungarian doctrine are also reflected, in an extent amplified, in some important documents adopted at the international level, particularly by the Council of Europe, Venice Commission and European Parliament. ${ }^{15}$

The first (chronologically) international statement to be analyzed is that of the Council of Europe, invested of the examination of three specific legal questions concerning the then proposed new Constitution of Hungary by the same Government of Budapest. The points 51-52 of the Opinion n. 614 of 28 March 2011 prepared by the European Commission for Democracy through Law (Venice Commission) ${ }^{16}$ relates to the future regulation of the Hungarian Constitution about cardinal/organic laws. In the Opinion, the question concerning cardinal laws is examined in connection with the analysis of the powers of the Constitutional Court in the draft new Constitution. In particular, the Venice Commission focuses on the problem of identifying the exact scope of the cardinal laws in the system of sources of law. Must, above all, clarify whether the cardinal laws-or organic laws-are subject to judicial control of constitutionality, or if they themselves represent a benchmark for reviewing the compliance with the Constitution of ordinary laws. The Venice Commission recommends that the first of the above solutions will be favourite, namely the subjection (also) of the cardinal laws to the judicial control of constitutional legality. In this case, however, a further problem lays, highlighted by the Venice Commission Opinion of March 2011. If, in fact, many fundamental aspects of the regulatory system in Hungary are regulated by organic laws, however, and not in the Constitution, it follows probably the danger of a sort of lack in constitutional review. ${ }^{17}$ For these reasons, the Venice Commission pointed out in the

Internazionale, January (2012) 931, 14 ff., who speaks of »authoritarian constitution«; Tóth, G.: La svolta ungherese spiegata ai marziani. Limes. Rivista italiana di geopolitica, (2012) 2, 305 ff., who denies that there was the feared autocratic turn; Scheppele, K. L.: The Unconstitutional Constitution. New York Times, 2-1-2012; Nadler, J.: Why Hungary's New Constitution Could Be Bad for Europe. Time, 5-1-2012; Association Européenne pour la Défense des Droits de l'Homme (AEDH), La nouvelle Constitution hongroise: une menace pour la démocratie et les droit. Bruxelles, AEDH, January 2012; Miklós, T. G.: Hongrie, laboratoire d'une nouvelle droite. Le Monde diplomatique, February 2012, 3, who states that the values which inspire the Hungarian Prime Minister Viktor Orbán are »travail, foyer, famille, nation, jeunesse, santé et ordre«; de Montety H.: La Hongrie en Europe. Revue des Deux Mondes, April 2012, 139 ff., where an examination of the changement de régime and a consideration of the Hungarian case as révélateur d'un dilemme européen.

14 See Chronowski: op. cit. 14.

15 For an effective synthesis, see Kelemen, K.: The New Hungarian Constitution: Domestic and European Criticalities, University of Trento European Coustitutional Law Student's Seminar Series.

16 The Venice Commission document (available on the Internet at http:// www. venice. coe. int.) has been prepared by a special working group, composed of five members. It was approved by the Venice Commission at its plenary session held in Venice from 25 to 26 March 2011. The components of the working group were the Austrian C. Grabenwarter, the German W. Hoffman-Riem, the Polish H. Suchocka, the Finnish K. Tuori and the Belgian J. Velaers.

17 In this sense it is set the final step of paragraph 51 of Opinion no. 614/2011. There it is stated, also, that »An extensive use of "cardinal laws" might lead to edging in stone the subjects regulated by such laws«. 
Opinion concerned that the discipline of the profiles of greatest relevance should be regulated directly in the Constitution, and not by sources of lower rank like cardinal/organic laws. This is true, the Commission concluded, for both rulings concerning the organization and functioning of the organs of the State and with regard to guarantees, and in particular the level of protection that must be constitutional, of individual rights and fundamental freedoms. ${ }^{18}$

The Venice Commission returned to examine the Hungarian Fundamental Law even after the adoption, on 18 April 2011, of the final text of the new Constitution by the Hungarian National Parliament. The request for action by the Venice Commission was presented this time by the Monitoring Committee set up by the Parliamentary Assembly of the Council of Europe (PACE). The Opinion no. 621 of 20 June 2011 was accordingly adopted by the Venice Commission at its Eighty-seventh plenary session, held in Venice from 17 to 18 June 2011. ${ }^{19}$ In paragraphs $22-27$ the Opinion of the Venice Commission deals with the cardinal laws contemplated by the new Hungarian Constitutional Charter. First, the Venice Commission notes that there are over fifty references contained in the Fundamental Law to matters to be regulated in the future by cardinal/organic laws, in addition of course to Article $\mathrm{T}$ where there is the definition of the cardinal law. The result according to the Commission-is that the main aspects of the Hungarian regulatory system will henceforth be governed by cardinal/organic laws. ${ }^{20}$

The Commission goes on to note that Hungarian cardinal laws are certainly not a unique situation in comparative law, where there are several experiences in which there are national organic laws. ${ }^{21}$ The feature of Hungarian cardinal laws would be to make more difficult to change the rules that relate to specific matters, which are sufficiently important to be removed from the realm of ordinary/simple laws, but at the same time need not be directly governed by constitutional rules. Ultimately, cardinal/organic laws are not of superprimary level, although for their approval (as well as for their modification) is established the need for a supermajority, not less than two-thirds of the members of Parliament present.

The Venice Commission, in the Opinion under consideration, ${ }^{22}$ recognized also that organic laws are already provided by the Hungarian constitutional law at the time of entry into force of the new Fundamental Law. However, and this is the problematic profile that the Commission intends to highlight, the concern stems mainly from the fact that cardinals or organic laws are contemplated in the new Constitution of Hungary in an exceptionally large manner, far beyond the traditionally issues covered in comparative law by organic laws, as is the case especially for the electoral law or regulations for parliamentary procedure.

18 See paragraph 52 of the Opinion cited in the note above.

19 The Opinion no. 621/2011 is available online at the website http:// www. venice. coe. int. The members of the working group were the same already part of the working group created for the adoption of Opinion no. 614/2011 (on the latter, see above).

20 See point 22 of the Opinion no. 621/2011.

${ }^{21}$ In the Italian doctrine, see widely Pegoraro, L.: Le leggi organiche. Profili comparatistici. Padova, CEDAM, 1990, and, by the same author and with specific reference to the legal systems of Central and Eastern post-socialist countries, the essay entitled: Il sistema delle fonti giuridiche nelle Costituzioni dell'Est europeo. Quaderni costituzionali, 1995, $111 \mathrm{ff}$.

22 See point 23. 
Going into detail, the Venice Commission notes that the constitutional regulation of the judicial system should be more analytical at the superprimary level, while the devolution of powers relating to the scope of legislation to be adopted with a supermajority is too extensive, that is through cardinal/organic laws. Moreover, the regulation concerning family social rights and tax law should be subtracted from the excessive intrusiveness of the cardinal laws, in order to provide greater flexibility to the provisions relating to the areas indicated. In other words, these are areas that should be regulated by ordinary laws, approved by a simple rather than two-thirds majority. ${ }^{23}$ In particular, is a convincing argument that of the Venice Commission for whom »Funcionality of a democratic system is rooted in its permanent ability to change. The more policy issues are transferred beyond the powers of simply majority, the less significance will future elections have and the more possibilities does a two-thirds majority have of cementing its political preferences and the country's legal order ${ }^{24}$. In conclusion, the Venice Commission noted that the scope of the cardinal laws appears unusually extended in the new Hungarian Constitution and so, it being understood that Member States are free to determine both the level of detail of the provisions of constitutional law that the different levels of internal legislation, ${ }^{25}$ the Commission moves towards a desirable narrowing of areas regulated by organic laws. ${ }^{26}$

The criticisms made by the Venice Commission were specifically mentioned and, therefore, reiterated by the European Parliament, by the resolution on the new Hungarian Constitution, adopted ${ }^{27}$ on 1 July 2011. In particular, in considerings L-N the resolution of the European Parliament examines Hungarian constitutional provisions concerning cardinal laws. It is noted in the resolution that the new Fundamental Law of Hungary establishes a wider use of the cardinal laws, in a manner such that their adoption can be defined as part of »the new Hungarian constitutional process $« .{ }^{28}$ It added that the adoption of specific and detailed rules through cardinal laws is likely to »endanger the principle of democracy «, ${ }^{29}$ because they create »more scope for a government with a two-thirds majority in order to cement our political preferences«, with the further consequence of diminished significance of future elections. ${ }^{30}$ Above all, it is the opinion of the European Parliament ${ }^{31}$ that $\gg$ the cultural, religious, socio-economic and financial politics should not be finally determined by cardinals laws $\ll{ }^{32}$ Based on these grounds, the European Parliament resolution on the part of the examination covering the cardinal laws has, on the one hand, invited the Hungarian authorities to adopt cardinal laws that are restricted, in the largest number of cases, to contain principle provisions, i.e. to take only »the scope of the basic regulation,

23 That is, according to rules of ordinary legislation and majoritarian politics, as is said in point 24 of the Opinion.

24 Thus is stated in point 24 of the Opinion.

25 With provision, then, of the step of cardinal/organic law in addition to that of ordinary law.

26 See points 25 and 27 of the Opinion.

27 With a majority of 331 votes in favor and 274 against.

28 See the considering $\mathrm{L}$, in the end.

29 See the considering $\mathrm{M}$.

30 See the considering quoted in the note above.

31 Which shares the concerns expressed about this issue by the Venice Commission in the two opinions above analyzed.

32 So in considering N. 
clearly defined $«{ }^{33}$ so as not to unduly constrain future choices and decisions of democratically elected governments and parliaments, while on the other hand has asked the European Commission to exercise the necessary supervision on the organic laws to be adopted, "so check that they are consistent with the EU acquis and in particular the Charter of Fundamental Rights of the European Union and with the letter and spirit of the treaties « ${ }^{34}$

In terms of comparison, it should be noted that there are currently legal systems of Western European countries and also of Eastern European post-communist countries that provide the organic laws.

This is the case of France, where Article 46 of the Constitution of 1958 provided for the first time organic laws in their modern version, ${ }^{35}$ designed to regulate important aspects of the organization of public powers, ${ }^{36}$ but not also the fundamental freedoms as is the case on the basis of Article 81 of the Spanish Constitution of 1978, which contains the

33 See point 1, lett. b), of the European Parliament's resolution.

${ }^{34}$ See point 2 of the resolution.

35 See the comparative analysis of Pegoraro, L.-Rinella, A.: Le fonti nel diritto comparato. Torino, 2000, 75 ff. See also Amiel, H.: Les lois organiques. Revue du droit public et de la science politique en France et à l'étranger, 1984, 405 ff., who at p. 406 states that »La Constitution du 4 octobre 1958 institue une nouvelle catégorie d'actes juridiques avec les lois organiques. L'existence de ce lois n'est certe pas récente puisqu'elle remonte à la Constitution de 1848. Mais, les nouvelles institutions de la France leur accordent una place et un rôle qu'elles n'avaient pas jusqu'à présent. En outre, la pratique est venue renforcer les caractères spécifiques des lois organiques«. The same author adds (ibid.) that »Il faut cependant souligner que, au-delà des divergences juridiques relatives à la définition de ces actes, la fonction des lois organiques reste toujours la même. L'Histoire constitutionnelle de la France, come d'ailleurs les comparaisons que l'on peut faire avec les pays étrangeres, démonstrent que les lois organiques ont une fonction constante dans l'ordonnancement juridique: compléter la constitution et en fixer les conditions d'application«.

${ }^{36}$ In the (not so wide) French legal literature, see Morange, G.: La hiérarchie des textes dans la Constitution du 4 octobre 1958. Recueil Dalloz, 1959, IV, Chronique, 21 ff.; Rousset, M.: La loi organique dans la Constitution du 4 octobre 1958. Recueil Sirey, 1960, XVIII, Chronique, 1 ss.; Sirat, C.: La loi organique et la Constitution de 1958, in Recueil Dalloz, 1960, XVIII, Chronique, 153 ff.; Amiel, H.: Les lois organiques. Revue du droit public et de la science politique en France et à l'étranger, op. cit., where the author highlights the caractére complémentaire des lois organiques, namely their nature of législation constitutionnelle complémentaire; Bérardo, J. P.: Les lois organiques dans l'ordonnancement constitutionnel français, in Scritti su le fonti normative e altri temi di vario diritto in onore di V. Crisafulli, II, Padova, CEDAM, 1985, 71 ff.; le Mire, P.: Article 46. In: Luchaire, F.-Conac, G. (eds): La Constitution de la République française. Paris, 1987, 2nd ed., 899 ff.; Mathieu, B.-Verpeaux, M. (eds): Les lois organiques et la mise en oeuvre de la révision constitutionnelle, Paris, Dalloz, 2009. For an unusual comparison, see also Saneewong Na Ayudthaya, K.: Les lois organiques: étude comparée France - Thaïlande. Analyse des lois organiques de France et Thaïlande. Saarbrücken, Éditions universitaires européennes, 2011. 
constitutional rules on organic laws ${ }^{37}$ (already contemplated in the authoritarian legal system of Franco's Spain ${ }^{38}$ ).

From the point of view of parliamentary procedure, the French organic laws cannot be approved, in the absence of agreement between the two Houses of Parliament, except with the affirmative vote by an absolute majority of its members by the National Assembly on final reading. Furthermore, the organic laws are not enacted until after the declaration of conformity to the Constitution by the Conseil constitutionnel. ${ }^{39}$ On the other hand, in the French constitutional system organic laws are approved by Parliament but, in some cases,

37 In the wide Spanish legal literature, see: Bermejo Vera, J.: Las fuentes del derecho en la Constitución española de 1978. In: Ramírez, M. (ed.): Estudios sobre la Constitución española de 1978. Zaragoza, 1979, 243 ff.; Gálvez Montes, J.: El ámbito material y formal de las leyes orgánicas. In: Dirección General de lo Contencioso del Estado: La Constitución Española y las Fuentes del Derecho. Madrid, 1979, II, 925 ff.; Martín Oviedo, J. M.: Tipología, jerarquía y producción de las normas en la Constitución española, ibid., 1294 ff.; Santamaría Pastor, J. A.: Las leyes orgánicas: Notas en torno a su naturaleza y procedimiento de elaboración. Revista del Departamento de Derecho Político, 1979, 46 ff.; Sosa Wagner, F.: Aproximación al tema de las leyes orgánicas. Civitas. Revista Española de Derecho Administrativo, (1979) 21, 199 ff.; Garrorena Morales, A.: El lugar de la ley en la Constitución española. Madrid, 1980; Id., Acerca de las leyes orgánicas y de su espuria naturaleza jurídica. Revista de Estudios Políticos, (1980) 13, 169 ff.; de la Quadra-Salcedo y Fernández del Castillo, T.: La Ley en la Constitución: leyes orgánicas. Civitas. Revista Española de Derecho Administrativo, (1980) 24, 37 ff.; Bastida Freijedo, F. J.: La naturaleza jurídica de las leyes orgánicas (Comentario bibliográfico). Revista Española de Derecho Constitucional, (1981) 2, 285 ff.; Fernández, T.-R.: Las leyes orgánicas y el bloque de la constitucionalidad. Madrid, 1981; Gimeno Gamarra, R.: Estado de la reforma de las leyes orgánicas y procesales. La Ley. Revista jurídica española de doctrina, jurisprudencia y bibliografia, 1981, 821 ff.; Linde, E.: Las leyes orgánicas parciales en la doctrina del Tribunal Constitucional. Revista de Administración Pública, (1981) 94, 339 ff.; Id., Linde Paniagua, E.: Leyes orgánicas: (un estudio de legislación y jurisprudencia). Madrid, 1990; Prieto Sanchís, L.: Las leyes orgánicas y el principio de jerarquía normativa en la Constitución española de 1978. Revista de la Facultad de Derecho de la Universidad Complutense, (1981) 62, 125 ff.; Pemán Gavín, J. M.: Sobre las Leyes Orgánicas en el Derecho Español: algunas observaciones a propósito de la Jurisprudencia constitucional. Revista Vasca de Administración Pública/Herri-Arduralaritzako Euskal Aldizkaria, (1984) 9, 29 ff.; Id., Sobre las leyes orgánicas en el Derecho español: algunas observaciones a propósito de la jurisprudencia constitucional. In: Martín-Retortillo Baquer, L.: De la jurisprudencia del Tribunal Constitucional. Seminario de profesores de la Facultad de Derecho. Zaragoza, 1985, 145 ff.; Jiménez-Blanco - Carrillo de Albornoz A.: De nuevo en torno a la leyes orgánicas, las bases y las competencias legislativas de las Comunidades Autónomas. Civitas. Revista Española de Derecho Administrativo, (1987) 53, 117 ff.; de Otto - Pardo, I.: Derecho constitucional. Sistema de fuentes. Barcelona, 1988, 2nd ed.; Romero Coloma, A. M.: Problematica de las leyes organicas. Actualidad Administrativa, (1993) 34, 431 ff.; Chofre Sirvent, J. F.: Significado y función de las leyes orgánicas. Madrid, 1994; Barceló i Serramalera, M.: Leyes orgánicas, derechos fundamentales y Comunidades autónomas. In: Aparicio Pérez, M. A. (a cura di): Derechos constitucionales y pluralidad de ordenamientos. Barcelona, 2001, 435 ff; Id., La ley orgánica: ámbito material y posición en el sistema de fuentes. Barcelona, 2005; Cordón Moreno, F.: Leyes Orgánicas Procesales. Cizur Menor (Navarra), 2002.

38 On the ideological bases of the Ley orgánica del Estado of January 10, 1967, see Montoro Ballestreros, A.: Ideologías y fuentes del derecho. Revista de Estudios Politicos, (1984) 40, 59 ff.

39 On judicial review of constitutionality of organic laws in French legal system, see Luchaire, F.: Les lois organiques devant le Conseil constitutionnel. Revue du droit public et de la science politique en France et à l'étranger, 1992, $389 \mathrm{ff}$. 
the Government may also adopt organic ordinances with equal value in terms of sources of law. ${ }^{40}$

With regard to the organic laws of the post-authoritarian Spain, the second paragraph of Article 81 of the 1978 Constitution states that »La aprobación, modificación o derogación de las Leyes orgánicas exigirá mayoría absoluta del Congreso, en una votación final sobre el conjunto del proyecto«. Unlike what happens in the French constitutional system, in Spain Articles 81-82 of the Constitution exclude that Parliament may authorize the Government to enact national organic texts through ordinances with the force of law.

Organic laws are also contemplated in the Portuguese Constitution of 1976, after the 1989 reform, ${ }^{41}$ as well as in Article 80 of the Greek Constitution of 1975, although in the latter case with characteristics of specialty. ${ }^{42}$

If we now consider the Eastern European post-communist legal systems in relation to organic laws, some (probably) lesser known and (above all) most problematic aspects emerge. Areas governed by organic laws on the basis of the constitutions are more extensive than what happens in the West.

This is the case, first, of Albania, whose Constitution ${ }^{43}$ of 1998 contains a very analytical framework of the organic laws, which cover large areas of national and local levels regulations. Organic laws, in fact, dictate the rules for the organization both of central state and local governments. Under Article 1, paragraph 2, of the Constitution need the reinforced support of three-fifths of the members of Parliament (Assembly) to pass laws concerning the organization and functioning of all institutions covered by the Constitution, the provisions on the legal status of public officials, the organization of territorial administration of the Albanian Republic. The right to vote is governed by organic laws, in relation to the nationality requirements of citizenship, the provisions concerning elections, political and administrative, general and local, as well as the regulation of referendums. And, also, the organic laws are related to all the rules contained in the codes, legislation on the state of emergency, the granting of amnesty. ${ }^{44}$ As one sees, there are really significant areas of operation of the organic laws adopted by reinforced majority. On the other hand, both the organic laws and "normal" laws are subject, as stated by Article 85, paragraph 1, of the Constitution of Albania, to the power of the President of the Republic to postpone the bill passed in Parliament for review. By doing so, we see that, roughly in the same way that now in Hungary, in the Albanian case the organic laws are contemplated by the Constitution, cover large areas of the legal system, and also participate in some aspects of the general

40 These are the ordonnaces portant loi organique, i.e. the so-called mesures organiques par voie d'ordonnance, on which see Maugius, R.: L'ordonnance en Droit public français contemporain. Lyon, Université de Lyon (Thèse doctorat), 1967.

${ }^{41}$ See Moreira da Silva, J. L.: Da lei orgânicas na Constituição da República Portuguesa. Lisboa, 1991; Blanco de Morais, C.: As leis reforçadas. As leis reforçadas pelo procedimenti no âmbito dos critérios estruturantes deas relações entre actos legislativos. Coimbra, 1998; Gomes Canotilho, J. J.: Il diritto costituzionale portoghese. Orrù, R. ed. (transl. of A. Ciammariconi, M. Mazza and R. Orrù), Torino, 2006, 173 f., where references to Articles 112.3 and 166.2 of the Portuguese Constitution.

${ }^{42}$ See Pantélis, A. M.: Les grands problèmes de la nuovelle Constitution hellenique, Foreword of L. Hamon, Paris, 1979, 288 ff.; Spyropoulos, P. C.-Fortsakis, T. P.: Constitutional Law in Greece, Athens-Alphen aan den Rijn (Netherlands), 2009, $71 \mathrm{ff}$.

43 In Albanian, Kushtetuta e Rrepublikës së Shqipërisë.

44 See, in detail, Loiodice, A.-Shehu, N.: La Costituzione albanese. Bari, 1999, 16 ff. 
rules regarding the legislative process (simple or aggravated). Among the first, it was the best Italian constitutional comparative doctrine to highlight that the laws of Article 81 of the Constitution of Albania should be classified in »comparative category of organic laws $\ll .{ }^{45}$

If we consider, then, the Croatian post-Yugoslav legal system, there are also many similarities with the Hungarian case. The Croatian post-communist Constitution was adopted on December 22, 1990 (cd Christmas Constitution, in Croatian Božićni Ustav), entered into force in $1991^{46}$ and was subsequently amended in 1998, 2000, 2001 and 2010. It establishes, in its current wording, that are regulated by organic laws, enacted by the "supermajority" of two-thirds of the members of (unicameral) Parliament, the rights of national minorities, as well as the provisions concerning human rights and fundamental freedoms, the national and local electoral systems, the organization and functioning of institutions and government agencies, public administration and the organization and powers of bodies of regional and local levels. ${ }^{47}$ In this case, the list is perhaps shorter than that provided by the Albanian Constitution, but does not appear altogether inferior in quality to that established by the new Hungarian Constitution. Despite this, the EU accession of Croatia-scheduled for July 1, 2013 ${ }^{48}$-does not seem to have encountered obstacles in that regard.

With regard, finally, to the legal system of a Central-Eastern European country that has already joined the European Union, stands the case of Romania, whose Constitution ${ }^{49}$ of 1991 (amended in 2003) ${ }^{50}$ provides for the level of organic laws, which are approved by the affirmative vote of a majority of the members of each House of Parliament, while the ordinary laws are adopted by a majority of members present in the two branches of the

45 See the fundamental considerations of Ganino, M.: La Costituzione albanese del 1998: alla ricerca dell'Europa. Diritto pubblico comparato ed europeo, 1999, 22 ff., and therein specifically p. 33 et seq., on the Constitutional State and the system of sources.

46 On the Croatian Constitution (Ustav Republike Hrvatske), among the so-called pioneer constitutions in the Eastern European countries, see Häberle, P.: The 1991 Croatian Constitution in the European Legal Comparison, in Politička misao - Croatian Political Science Review (edited by the Faculty of Political Science of the University of Zagreb, in Croatian Fakultet političkih znanosti Sveučilišta u Zagrebu), 2000, no. 1, 49 ff.; S. Sokol, Croatia as a Democratic Constitutional State, ivi, 1998, n. 3, 112 ff.

47 See Article 83 of the present Croatian Constitution.

48 In Croatia's referendum on accession to the European Union, held on 22 January 2012, there was a clear majority in favor (two thirds of valid votes, exactly 66,27 per cent), although the turnout was very low, amounting to 43,51 per cent of those entitled to vote. See Traynor, I.: Croatia votes to join EU. Balkan state ready to become 28th member of the European Union as referendum delivers an overwhelming yes vote. The Guardian, 22-1-2012, where it is recalled that the Prime Minister, the social democrat leader Zoran Milovanović, said that »The turnout could have been better«, adding that »It's not brilliant. Probably because of the situation in the country«.

49 In Romanian, Constituţia României.

50 See Febbrajo, A. M.: Il costituzionalismo romeno nella post-transizione. Diritto pubblico comparato ed europeo, 2011, 211 ff.; Tănăsescu, E. S.: Modern Romanian Constitutionalism under the Influence of EU Accession, ivi, 2011, $225 \mathrm{ff}$. On the constitutional history of Romania, see Febbrajo, A. M.: Modelli costituzionali nella Romania pre-comunista: una analisi comparativa. Diritto pubblico comparato ed europeo, 2009, $511 \mathrm{ff}$. (where references to Romanian Constitution of 1866 and 1923). 
National Parliamentary Assembly. ${ }^{51}$ The areas assigned to the jurisdiction of the organic laws are very extensive, since the third paragraph of Article 73 of the Constitution of Romania stipulates that: »Organic laws shall regulate: a) the electoral system; the organization and functioning of the Permanent Electoral Authority; b) the organization, functioning, and financing of political parties; c) the statute of Deputies and Senators, the establishment of their emoluments and other rights; d) the organization and holding of referendum; e) the organization of the Government and of the Supreme Council of National Defence; f) the state of partial or total mobilization of the armed forces and the state of war; g) the state of siege and emergency; h) criminal offences, penalties, and the execution thereof; i) the granting of amnesty or collective pardon; j) the statute of public servants; $k$ ) the contentious business falling within the competence of administrative courts; 1) the organization and functioning of the Superior Council of Magistracy, the courts of law, the Public Ministry, and the Court of Audit; m) the general legal status of property and inheritance; n) the general organization of education; o) the organization of local public administration, territory, as well as the general rules on local autonomy; $p$ ) the general rules covering labour relations, trade unions, employers' associations, and social protection; q) the status of national minorities in Romania; r) the general statutory rules of religious cults; s) the other fields for which the Constitution stipulates the enactment of organic laws «. ${ }^{52}$

3. Some useful indications about the role and functions of cardinal laws in the new Hungarian constitutional order can perhaps be found by examining the relevant provisions of the Magyar Constitution in force until December 31, 2011. It was-as known-the

51 Thus established, respectively, by the first and second paragraph of Article 76 of the Romanian Fundamental Law.

52 English translation of the constitutional text is taken from the website of the Chamber of Deputies of Romania (http:// www. cdep. ro). In a limited number of issues, there are also organic laws in the Slovenian Constitution (Ustava Republike Slovenije) of 1991, amended in 1997, 2000, 2003 and 2004. It must be remembered, in fact, that Article 80, paragraph 4, states that the electoral law for the National Assembly (Parliament) is approved by two-thirds majority of the members of Parliamentary Assembly, Article 90, paragraph 5, requires the adoption of the law on national referendum (legislative referendums) by the affirm/ative vote of two thirds of the members present and Article 124, paragraph 1, establishes that $\gg$ The form, extent and organisation of the defence of the inviolability and integrity of the national territory shall be regulated by a law adopted by the National Assembly by a two-thirds majority vote of deputies present«. See Perenič, A.: La nuova Costituzione slovena. Quaderni costituzionali, 1994, 307 ff.; The New Constitutional System of Slovenia, Ljubljana, Univerza v Ljubljani Pravna fakulteta [University of Ljubljana Faculty of Law], 1992 (Zbornik znanstvenih razprav-ZZR/Proceedings of scientific research). In the prospect of the comparison between the laws of the South Slavs, see also Nikolić, P.: I sistemi costituzionali dei nuovi Stati dell'ex-Jugoslavia, with introductory essay by S. Gambino, Torino, 2002; Marko, J.: Die neuen Verfassungen: Slowenien - Kroatien - Serbien. Ein Vergleich. In: Marko, J.-Borič, T. (eds): Slowenien - Kroatien - Serbien. Die neuen Verfassungen. Graz-Wien-Köln, 1991, 1 ff. 
Constitution of $1949,{ }^{53}$ amended several times both before ${ }^{54}$ the "revolutionary" events of 1989 and (with considerable intensity) after ${ }^{55}$ those same events themselves.

It is useful to remember ${ }^{56}$ that the former Constitution provided for two types of laws, namely, the ordinary laws and special-majority laws. The latter, also called super-majority laws, were, in turn, of two types. On the one hand, there were laws to be adopted by a majority of two thirds of the members of Parliament present and, on the other hand, the laws to be approved by the super-majority of two thirds of the members of the National Parliamentary Assembly. The Hungarian Constitutional Court, ${ }^{57}$ in the judgment no. 1 of

53 The Act XX of 1949 was the first written constitution of Hungary. On it see, for example, Kovács, I.: Le droit constitutionnel, in AA.VV., Introduction au droit de la République populaire hongroise, Foreword of M. Ancel and Introduction of I. Szabó, Paris, 1974, 33 ff.; Péteri, Z.: The Declaration of the Rights of Man and Citizen and the Hungarian Constitution. Acta Juridica Hungarica. Hungarian Journal of Legal Studies, (1991) 1-2, 57 ff.; Dobrocsi, S.: Constitutional History of Hungary: A Short Survey, University of Trento European Coustitutional Law Student's Seminar Series.

${ }^{54}$ See, in the Italian-speaking literature, Lipschitz, G.: Prime considerazioni sugli emendamenti della Costituzione ungherese. Rivista trimestrale di diritto pubblico, 1984, $830 \mathrm{ff}$.

55 See the careful reconstruction of Drinóczi, T.: Revisione e manutenzione costituzionale nell'ordinamento ungherese. In: Palermo, F. (ed.): La »manutenzione» costituzionale, Padova, CEDAM, 2007, 437 ff., and most recently, by the same author, Constitutional Politics in Contemporary Hungary (1991-2011), in this volume. See, also, Halmai, G.: The reform of constitutional law in Hungary after the transition. Legal Studies, 1998, 188 ff.; Paczolay, P.: The New Hungarian Constitutional State: Challenges and Perspectives. In: Howard, A. F. D. (ed.): Constitution Making in Eastern Europe. Washington (DC), 1993, 21 ff. Inclusive (and very detailed, for a total of 692 pages) of periods pre-and post-1989 is the analysis of Jakab, A.-Takacs, P.-Tatham, A. F. (eds): The Transformation of the Hungarian Legal Order 1985-2005, Alphen aan den Rijn (Netherlands), 2007.

56 See Dezső, M. (ed.): Constitutional Law in Hungary. Alphen aan den Rijn (Netherlands), $2010,63 \mathrm{ff}$.

57 For the Hungarian model of constitutional jurisdiction prior to the Constitution in force since 2012, see Mazza, M.: Tendenze della giurisprudenza costituzionale ungherese nella prospettiva dei rapporti tra diritto nazionale e diritto europeo dei diritti umani. Diritto pubblico comparato ed europeo, 2006, 1441 ff.; Id., Rapporto Ungheria, in Ganino, M.-Filippini, C.-Di Gregorio, A.-Mazza, M.: Corti costituzionali e Corti europee: i casi di Federazione di Russia, Polonia, Repubblica Ceca, Ungheria. In: Ferrari, G. F. (ed.): Corti nazionali e Corti europee (Collana »Cinquanta anni della Corte costituzionale della Repubblica italiana«), Napoli, 2006, specifically 139 ff.; Pištan, Č.: La giustizia costituzionale nell'Europa centro-orientale: le esperienze di Croazia, Slovenia, Polonia, Ungheria. In: Mezzetti, L. (ed.): Sistemi e modelli di giustizia costituzionale. I, Padova, CEDAM, 2009, 393 ff.; Sólyom, L.-Brunner, G.: Constitutional Judiciary in a New Democracy. The Hungarian Constitutional Court, Foreword of S.G. Breyer, Ann Arbor, 2000 (and here also, at 103-378, a wide selection of decisions adopted by the Constitutional Court of the Republic of Hungary); Adam, A.: La Cour constitutionnelle en Hongrie. In: de Vergottini, G. (ed.): Giustizia costituzionale e sviluppo democratico nei Paesi dell'Europa centro-orientale (proceedings of the conference of Bologna, 12 and 13-11-1999), Torino, 2000, 207 ff.; Kovács, P.: Introduction à la jurisprudence de la Cour constitutionnelle de la République de Hongrie. Approche Thématique. Regensburg, 2011 (Entwicklungen im Europäischen Recht/Developments in European Law/Développements en Droit Européen, Bd. 1); Kerek, A.: Verfassungsgerichtsbarkeit in Ungarn und Rumänien. Ein Vergleich der Verfassungsgerichtsbarkeiten zweier osteuropäischer Transformationsstaaten auf ihrem Weg zum konsolidierten Rechtsstaat. Berlin, 2010 (Schriftenreihe zum Osteuropäischen Recht, Bd. 14). With respect to the control of constitutionality in the Hungarian Socialist law, see Kuss, K.-J.: New 
$1999,{ }^{58}$ ruled that the aggravated majority established in the Constitution for the enactment of the law is not just a formal requirement of the legislative process, but constitute a special superprimary guarantee designed to protect the need of achieving broad convergence among members of Parliament as to the regulation of certain matters of particular relevance. Earlier, in the ruling no. 4 of 1993, the Hungarian Constitutional Court had held that the fact of requiring a special majority for approval of certain laws does not mean in any way creating a sort of hierarchy of fundamental rights, since organic laws are not constitutional parameter for ordinary laws. Again intervening in relation to the so-colled two-thirds laws, the Hungarian Constitutional Court decided, with the judgment no. 3 of 1997 in which are proposed to a large extent the arguments already made in the above-mentioned judgment no. 4 of 1993, that not the entire matter for which the Constitution provides the organic law should be regulated by organic law, i.e. by a law for whose approval is required the twothirds majority, but the organic law itself must ensure the direct implementation of the constitutional provision, subject to subsequent adoption of one or more ordinary laws for the discipline of detail, of course within the general framework and in accordance with the principles established by the special-majority law.

With particular reference to the, politically very significant, area of fundamental rights, that means-in the opinion of the Hungarian judges of the constitutional legitimacy-that the essential aspects of fundamental rights, including guarantees for the implementation of fundamental rights as well as limits to the constitutional restrictions of fundamental rights, can only be established through the adoption of special-majority laws, whereas aspects of detail, including any additional guarantees as well as implementing "adjustments" necessitated by changed circumstances, are likely to be introduced in the same field by ordinary laws. ${ }^{59}$ Ultimately, the combined reading of decisions no. 4/1993 and no. 3/1997 of the Hungarian Constitutional Court allowed the conclusion that the regulation of fundamental rights can be shared between ordinary laws and laws to be adopted by a majority of two thirds, provided that ordinary laws do not alter or contradict the rules dictated by organic laws.

Shifting attention now from the side of constitutional adjudication to that of the Hungarian scholarship before the new Constitution in force since the beginning of 2012, the issue regarding the possibility of the control of constitutionality by the Constitutional Court of all laws passed by the National Parliament, both by a simple majority and by a reinforced majority of two thirds was first successfully resolved..$^{60}$ The Hungarian scholarship of public law had also deepened, from the point of view of the hierarchy of sources of law, the relations between ordinary laws and laws for whose approval a reinforced majority is

Institutions in Socialist Constitutional Law: The Polish Constitutional Tribunal and the Hungarian Constitutional Council. Review of Socialist Law, 1986, 343 ff., where informations can be found concerning the Constitutional Council (in Hungarian, Alkotmányjogi Tanács) created in 1983 and governed by Article 21, paragraphs 3-4, of the Constitution and the Law I of 1984 on the Constitutional Council adopted by the Hungarian National Assembly (Parliament) April 26, 1984 (Law on the Constitutional Council, in Hungarian Törvény az Alkotmányjogi Tanácsról).

58 For some references to this constitutional decision, see De Simone, M.: Ungheria: la nuova Costituzione. Verso una deriva autoritaria? Forum of Quaderni costituzionali (www. forumcostituzionale. it, doc. dated 16-9-2011), 8.

59 Id est, simple majority laws.

${ }^{60}$ In that sense, commenting on Article 32/A, paragraphs 1-2, of the Constitution previously in force, Dezső: Constitutional Law in Hungary. op. cit. 67. 
required ${ }^{61}$ It was observed, in particular, that the level of special-majoirty laws is hierarchically higher than that of ordinary laws, as demonstrated inter alia by the observation that while ordinary laws cannot amend the laws to be adopted by an aggravated majority of two thirds, the latter can definitely change ordinary laws. In any case, if a law is passed by simple majority instead of a law adopted by a reinforced majority in an area reserved to organic law, ordinary law will be considered unconstitutional because it violated the Constitution and does not, however, because it has violated the provisions of the law approved by a majority of two thirds. In the wake of doctrinal elaboration, also the constitutional jurisprudence passed from the affirmation that ordinary laws are different from laws which must be approved by a majority of two thirds only from a procedural standpoint, to the different position according to which the special-majority laws are to be placed in the hierarchy of norms on a higher level than ordinary laws. ${ }^{62}$ In particular, the judgment of the Constitutional Court no. 1 of 1999 explicitly stated that ordinary laws (adopted by simple majority) cannot in any way modify or repeal the super-majority laws, since the latter are compared to the first in a higher position in the hierarchy of sources of law. If this happens, ordinary law would be unconstitutional, specifying that the violation of the Constitution would be in the case under consideration for failure to comply with an interposed rule. ${ }^{63}$

4. To conclude, it must first be noted that, between December 2011 and the early months of 2012, many ordinary laws, ${ }^{64}$ and even some cardinal laws for the implementation of the new Fundamental Law, were approved by the Hungarian Parliament. The cardinal laws refer, in particular, to protection of the family ${ }^{65}$ and to religious freedom as well as to the relations between the State and religious organizations/associations. ${ }^{66}$ These laws must be evaluated by the Venice Commission, to which the same laws have been sent February $21,2012 .{ }^{67}$

${ }^{61}$ See Jakab, A.: A magyar jogrendszer szerkezete [The structure of the Hungarian legal system]. Budapest, 2007, $151 \mathrm{ff}$.

${ }^{62}$ See, comparatively, the rulings contained in the judgments no. $4 / 1993$ and no. $1 / 1999$ of the Constitutional Court.

${ }^{63}$ On hierarchical position and typology of interposed rules, see recently Cicconetti, S. M.: Tipologia, funzione, grado e forza delle norme interposte. Diritto e società, 2011, $721 \mathrm{ff}$.

${ }^{64}$ In his speech to the European Parliament on 18 January 2012, the Prime Minister Viktor Orbán has spoken of 365 laws passed by the Hungarian Parliament in the first twenty months after the elections of April 2010.

65 Cardinal law no. CCXI of December 23, 2011. The Fundamental Law provides that cardinal laws for the implementation of Fundamental Law can be approved before the entry into force of the new Fundamental Law. With specific reference to the family, the new Constitution explicitly privileges heterosexual marriage: see Uitz, R.: Lessons from Sexual Orientation Discrimination in Central Europe. American Journal of Comparative Law, 2012, $235 \mathrm{ff}$. (in the prospect of the comparison with the Polish and Slovenian legal systems).

${ }^{66}$ Cardinal law no. CCVI of December 30, 2011.

67 As stated by Courrier: À propos des »évènements politiques en Hongrie»... Quelques clés pour en comprendre le débat juridique, op. cit., 315, »En réalité, les interrogations soulevées par les institutions européennes de Strasbourg ou de Bruxelles relèvent non pas tant du texte constitutionnel mais des "loi cardinales" $"$. 
Secondly, it can be observed that, in light of the comparison between the legal systems of Western and Eastern Europe made above, ${ }^{68}$ the areas reserved by the new Hungarian Fundamental Law are especially large, and have an equal perhaps only in Romanian constitutional law.

Thirdly, the comparison with the Hungarian constitutional law before the entry into force of the Fundamental Law of 2012 shows that there was an extension of the areas reserved to the regulation by cardinal laws, since these areas were up to thirty-three in December 2011 and now, with the entry into force of the new Fundamental Law, they are thirty-nine. ${ }^{69}$

Ultimately, though it can be certainly said that organic laws are contemplated in many constitutional systems of Western countries as well as of Eastern European post-Communist countries, is the wideness of matters reserved to cardinals laws in Hungarian legal system that presents very unusual characters, so it can be assumed, even taking account of the first cardinal laws enacted, that they serve more to make it difficult to change in future choices of the majority, rather than to ensure minorities. ${ }^{70}$ In this perspective, the new "partisan" Fundamental Law could also be considered a so-called core constitution (or shorter Basic Law), since the detailed regulation is and will be contained in the cardinal laws.

${ }^{68}$ See ante, in paragraph 2.

${ }^{69}$ On this point, see Csink-Schanda-Varga (eds): The Basic Law of Hungary. A First Commentary, op. cit. 16.

70 Data available on the website of the Hungarian parliament (http:// www. mkogy. hu) allow to know that the laws, both ordinary and cardinal, have been massively voted by the majority of deputies belonging to Fidesz, sometimes with the participation of the opposition parliamentarians belonging to the far-right party Jobbik, therefore without the support of the center-left Socialist Party and the Greens. 